\title{
Heavy Metals in Brown Bears from the Central European Carpathians
}

\author{
O. ČELECHOVSKÁ ${ }^{1}$, I. LITERÁK ${ }^{1}$, S. ONDRUŠ² ${ }^{2}$ Z. POSPÍŠIL ${ }^{1}$ \\ ${ }^{1}$ University of Veterinary and Pharmaceutical Sciences, Brno, Czech Republic \\ ${ }^{2}$ Administration of the National Park Low Tatras, Banská Bystrica, Slovakia \\ Received February 7, 2006 \\ Accepted June 30, 2006
}

\begin{abstract}
Čelechovská O., I. Literák, S. Ondruš, Z. Pospíšil: Heavy Metals in Brown Bears from the Central European Carpathians. Acta Vet. Brno 2006, 75: 501-506.

The aim of the present study was to assess heavy metal load in the brown bear (Ursus arctos) living in the central European Carpathians. Between 2002 and 2004, fifteen bears were examined to evaluate the distribution of cadmium, lead, mercury and copper in the animals' muscles (diaphragm), spleen, liver and kidney. The highest content of cadmium, lead and mercury was found in the kidney $\left(17.4 \pm 5.2 \mathrm{mg} \cdot \mathrm{kg}^{-1}, 1.16 \pm 0.39 \mathrm{mg} \cdot \mathrm{kg}^{-1}, 0.39 \pm 0.25 \mathrm{mg} \cdot \mathrm{kg}^{-1}\right)$, whereas the lowest content of the metals was observed in the muscles $\left(0.017 \pm 0.009 \mathrm{mg} \cdot \mathrm{kg}^{-1}, 0.299 \pm 0.308\right.$ $\left.\mathrm{mg} \cdot \mathrm{kg}^{-1}, 0.013 \pm 0.011 \mathrm{mg} \cdot \mathrm{kg}^{-1}\right)$. Second highest concentration of cadmium, lead and mercury was detected in the liver $\left(0.83 \pm 0.24 \mathrm{mg} \cdot \mathrm{kg}^{-1}, 0.99 \pm 0.61 \mathrm{mg} \cdot \mathrm{kg}^{-1}, 0.11 \pm 0.05 \mathrm{mg} \cdot \mathrm{kg}^{-1}\right)$. Copper distributions and concentrations in bear tissues were as follows (in descending order): liver $\left(23.9 \pm 6.7 \mathrm{mg} \cdot \mathrm{kg}^{-1}\right),>$ kidneys $\left(9.0 \pm 3.3 \mathrm{mg} \cdot \mathrm{kg}^{-1}\right),>$ muscles $\left(1.9 \pm 1.6 \mathrm{mg} \cdot \mathrm{kg}^{-1}\right)$ and $>$ spleen $\left(1.0 \pm 0.2 \mathrm{mg} \cdot \mathrm{kg}^{-1}\right)$. As compared with heavy metal load observed in bear tissues between 1988 and 1990, the concentration of cadmium in the muscles and liver was significantly lower $(p<0.01)$. On the contrary, mercury values were significantly higher in the liver $(p<0.05)$, kidney and muscle $(p<0.01)$. Lead and copper tissue concentrations did not change substantially.
\end{abstract}

Cadmium, Lead, Mercury, Copper, AAS, the Low Tatras

Heavy metals are a part of the Earth's crust and their biosphere incidence, distribution and form are influenced by anthropogenic activities rather than natural processes (Nriagu 1988, 1991; Nriagu and Pacyna 1988). Once released in the biosphere, metals persist for a long time while they may change their forms and dissolve (MacDonald et al. 2000). Immissions caused by burning fossil fuels and waste, car exhausts and residua of widely used pesticides can result in the environment contamination by inorganic and organic compounds. Chemical contamination of the environment impairs ecological balance. Sensitive plant species are affected, large forest areas are destroyed and toxic substances enter the food chain (Yaaqub et al. 1991; Gnamus et al. 1995; 2000). Even an insignificant concentration of these substances can, in the long run, endanger the health of the flora and fauna (Y a aqu b et al. 1991; Massanyi et al. 2000ab; B eiglblock et al. 2002; Hell et al. 2005; Massanyi et al. 2005). Some wild animal species, especially predators representing the last component of the food chain, can be seen as bioindicators of environmental contamination by inorganic and organic pollutants (Gufler et al. 1997; Dietz et al. 2000; Hoekstra et al. 2003; MacDonald et al. 2005).

One of the top predators with a typical food strategy is the brown bear (Ursus arctos), living in Eurasian and North American areas that have been almost untouched by human activities. The bears of Central Europe live mainly in the Carpathians. Although inorganic and organic tissue contaminants in polar bears from various polar areas have been described relatively sufficiently (Dietz et al. 2000; Muir et al. 1999; Hoekstra et al. 2003; et al. $2001 \mathrm{ab}$ ), heavy metal tissue concentrations of the brown bear have been studied only sporadically. Heavy metals in brown bear tissues were detected in the Karelian area of

Address for correspondence:

Doc.Ing. Olga Čelechovská, Ph.D.

Department of Biochemistry, Chemistry and Biophysics

Faculty of Veterinary Hygiene and Ecology

University of Veterinary and Pharmaceutical Sciences

Palackého 1-3, 61242 Brno, Czech Republic

Phone + 420541562606

E-mail: celechovskao@vfu.cz

http://www.vfu.cz/acta-vet/actavet.htm 
Russia (Medvedev 1999) and in the western Carpathians of Slovakia (Chudík and Maňkovská 1989; Žilinčar et al. 1992). Heavy metal contamination in the Slovak Carpathians can be influenced by industrial plants affecting the local environment for the past several decades. They are mainly thermal power stations consuming brown coal (Keegan et al. 2006), copper and aluminium works (Wilcke et al. 1998, 1999), or extractive industry (Miadoková et al. 2000). A direct connection between air pollution and contamination of animals was reported in previous studies (Tataruch and Onderschek 1991; Chudík and Maňkovská 1987).

The aim of our study was to determine the content and distribution of cadmium, lead, mercury and copper in tissues of brown bears living in the western Carpathians of central Slovakia between 2002 and 2004, to compare heavy metal concentrations with the values observed in the same location between 1988 and 1990 (Žilinčar et al. 1992), and to comment on the overall dynamism.

\section{Materials and Methods}

We examined tissue samples of 15 brown bears (Ursus arctos) from the orographic area of the Low Tatras mountain range. The Low Tatras, located in central Slovakia, make a central part of the western Carpathians. Tissues were collected from bears that were shot down during regulatory shooting (approved by the Ministry of the Environment of the Slovak Republic) in the autumn of 2002 (6 bears), 2003 (2 bears) and 2004 ( 7 bears). Sex distribution, body weight and age data are presented in Table 1. Samples of muscle (diaphragm), liver, spleen and kidneys were collected immediately after the shooting (no later than 12 hours after the death). Each sample was stored in a separate plastic bag at $-18^{\circ} \mathrm{C}$ in a freezing box until the analysis was performed.

Table 1. Characteristics of examined bears

\begin{tabular}{|c|c|r|r|l|}
\hline Sex & $\mathrm{n}$ & \multicolumn{2}{|c|}{ Weight $(\mathrm{kg})$} & $\begin{array}{c}\text { Age (year) } \\
\text { min }-\max \end{array}$ \\
\hline $\mathrm{F}$ & 10 & $108 \pm 26$ & $67.5-158$ & $5.7 \pm 1.6$ \\
$\mathrm{M}$ & 5 & $117 \pm 41$ & $53-175$ & $5.7 \pm 2.4$ \\
\hline
\end{tabular}

Mercury, cadmium, lead and copper tissue concentrations were estimated. Mercury concentration was determined using dedicated AMA 254 mercury analyzer (Altech Ltd., Czech Republic). Cadmium, lead and copper detection was performed using flameless Atomic absorption spectroscopy (AAS) on Z-5000 appliance (Perkin Elmer Corp, USA). Detection limits of individual elements $(3 \sigma)$ and certified reference materials (SRM 1577b bovine liver, BCR No 184 - bovine muscle, BCR No 186 - pig kidney) used for the verification of accuracy and suitability of the methods are described in Table 2. Pre-analytic preparation was based on the dissolution of samples by a mixture of nitric acid and hydrogen peroxide in a high-pressure laboratory microwave autoclave Uniclever (Plasmatronika, Poland). Means, standard deviations, Pearson correlation and separate variance $t$-test were carried out using statistical package Unistat 5 version 5.1 .

Table 2. Limit of detection of method (LOD) and element concentration \pm standard deviation in standard reference material of bovine liver (SRM 1577 b) and bovine muscle (BCR No 184).

\begin{tabular}{|c|c|c|c|c|c|}
\hline \multirow[t]{2}{*}{ Element } & \multirow{2}{*}{$\begin{array}{c}\text { LOD } \\
\mu \mathrm{g} \cdot \mathrm{kg}^{-1}\end{array}$} & \multicolumn{2}{|c|}{ SRM 1577b } & \multicolumn{2}{|c|}{ BCR No. 184} \\
\hline & & $\mathrm{mg} \cdot \mathrm{kg}^{-1}$ & Certified & $\mathrm{mg} \cdot \mathrm{kg}^{-1}$ & Certified \\
\hline $\mathrm{Cd}$ & 1.02 & $0.511 \pm 0.039$ & $0.500 \pm 0.030$ & $0.012 \pm 0.003$ & $0.013 \pm 0.002$ \\
\hline $\mathrm{Pb}$ & 9.31 & $0.133 \pm 0.005$ & $0.129 \pm 0.004$ & $0.234 \pm 0.011$ & $0.239 \pm 0.011$ \\
\hline $\mathrm{Cu}$ & 70.4 & $163 \pm 6$ & $160 \pm 8$ & $2.30 \pm 0.08$ & $2.36 \pm 0.06$ \\
\hline $\mathrm{Hg}$ & $0.01 *$ & - & - & $0.0031 \pm 0.0003$ & $0.0026 \pm 0.0006$ \\
\hline
\end{tabular}

* Limit of detection of AMA-254 


\section{Results and Discussion}

Mean concentrations in native tissues, standard deviations, medians and concentration ranges of cadmium, lead, mercury and copper in male and female bears are presented in Table 3. Significant differences between the males and females and individual elements $(\mathrm{Cd}$, $\mathrm{Pb}, \mathrm{Hg}$, and $\mathrm{Cu}$ ) were not found. This fact corresponds with the result described by Medvedev (1999).

Table 3. Mean element concentrations ( $\mathrm{c} \pm$ standard deviation), range and median in native tissues of bears

\begin{tabular}{|l|c|r|c|c|c|}
\hline Element & Tissue & $\mathrm{n}$ & $\mathrm{c} \pm$ s.d. & $\mathrm{c}_{\min }-\mathrm{c}_{\max }$ & Median \\
\cline { 4 - 6 } & & & \multicolumn{2}{|c|}{$\mathrm{mg} \cdot \mathrm{kg}^{-1}$} & \\
\hline $\mathrm{Cd}$ & muscle & 9 & $0.017 \pm 0.009$ & $0.009-0.042$ & 0.015 \\
& spleen & 12 & $0.072 \pm 0.024$ & $0.031-0.112$ & 0.073 \\
& liver & 12 & $0.829 \pm 0.240$ & $0.58-1.24$ & 0.782 \\
& kidney & 7 & $17.36 \pm 5.22$ & $9.08-27.32$ & 16.44 \\
\hline $\mathrm{Pb}$ & muscle & 9 & $0.299 \pm 0.301$ & $0.068-0.932$ & 0.162 \\
& spleen & 12 & $0.165 \pm 0.062$ & $0.10-0.34$ & 0.142 \\
& liver & 12 & $0.990 \pm 0.609$ & $0.41-2.62$ & 0.767 \\
& kidney & 7 & $1.158 \pm 0.391$ & $0.65-1.73$ & 1.235 \\
\hline $\mathrm{Cu}$ & muscle & 9 & $1.91 \pm 1.57$ & $0.92-4.88$ & 1.13 \\
& spleen & 12 & $0.97 \pm 0.22$ & $0.70-1.47$ & 0.88 \\
& liver & 12 & $23.9 \pm 6.72$ & $12.2-39.3$ & 24.3 \\
& kidney & 7 & $9.0 \pm 3.29$ & $4.62-14.01$ & 7.82 \\
\hline $\mathrm{Hg}$ & muscle & 9 & $0.013 \pm 0.011$ & $0.0003-0.04$ & 0.010 \\
& spleen & 12 & $0.017 \pm 0.012$ & $0.001-0.025$ & 0.014 \\
& liver & 12 & $0.107 \pm 0.048$ & $0.031-0.172$ & 0.098 \\
& kidney & 7 & $0.386 \pm 0.250$ & $0.103-0.699$ & 0.251 \\
\hline
\end{tabular}

Table 4. Proportional representation of elements in tissues

\begin{tabular}{|l|c|c|c|c|}
\hline Element & $\mathrm{Cd}$ & $\mathrm{Pb}$ & $\mathrm{Hg}$ & $\mathrm{Cu}$ \\
\hline Tissue & \multicolumn{4}{|c|}{$\% \pm$ s.d. } \\
\hline kidney & 100 & 100 & 100 & $37 \pm 11$ \\
liver & $6.1 \pm 1.4$ & $94 \pm 30$ & $46 \pm 17$ & 100 \\
spleen & $0.53 \pm 0.09$ & $20 \pm 4$ & $8.7 \pm 3.0$ & $6.0 \pm 1.2$ \\
muscle & $0.10 \pm 0.04$ & $57 \pm 9$ & $5.9 \pm 1.8$ & $5.3 \pm 2.6$ \\
\hline
\end{tabular}

Table 4 shows the distribution of individual elements in various tissues. Metal tissue distribution was assessed as an average representation (in \%) of concentration of each element in the native tissue as compared with the tissue showing the highest concentration of the same element in each individual animal ( \pm standard deviation). Kidney basic concentration (100\%) was selected for cadmium, lead and mercury; copper distribution was assessed in liver.

\section{Cadmium}

Cadmium showed the most marked, highly significant differences $(p<0.001)$ in concentration among individual tissues (Tables 3 and 4). The highest cadmium concentration was found in the kidney, the lowest concentration $(1000 \times$ lower) was observed in the muscle (diaphragm). Lower concentration was determined in the liver and spleen. Cadmium accumulation in the kidney and liver has been reported also in other mammals (Braune et al 1999; Muir et al. 1999; Kottferová and Koréneková 2000; Beiglbock et al. 2002; Gašparik et al. 2004; Kramarová et al. 2005). 
Cadmium concentrations determined in bear kidneys shot down between 2002 and 2004 were not statistically different from values described in bears examined between 1988 and 1990 (Žilinčar et al. 1992). However, the cadmium content in the liver and muscle (diaphragm) was significantly lower $(p<0.01)$.

\section{Lead}

The highest lead concentrations were found in the kidney. Concentration values in the liver were not significantly different from the kidney values. Highly significant difference in lead concentrations was observed between the kidney and muscle (diaphragm) $(p<0.001)$, kidney and spleen $(p<0.001)$, liver and muscle (diaphragm) $(p<0.005)$, and liver and spleen $(p<0.001)$. We found a significant correlation between the liver and kidney $(\mathrm{r}=0.70, p<0.05)$.

Changes of lead concentration in the muscle (diaphragm), liver and kidney as compared to values reported between 1988 and 1990 were not significant.

\section{Mercury}

A correlation between the body weight and mercury content was found in the kidney $(\mathrm{r}=0.89, p<0.01)$, which is in accordance with the cumulative function of mercury in the organism. Mercury cumulated in the tissues in the following order: kidney $>$ liver $>$ spleen $>$ muscle (diaphragm). A significant difference in the mercury concentration was observed between diaphragm and spleen $(p<0.05)$ and liver and kidney $(p<0.05)$, while a highly significant difference was determined between the muscle (diaphragm) and liver, spleen and liver, muscle (diaphragm) and liver $(p<0.001)$, and spleen and kidney $(p<0.01)$.

It should be emphasized that mercury concentration in the liver was significantly higher $(p<0.05)$ compared to values determined between 1988 and 1990; the difference between the kidney and diaphragm was even higher $(p<0.01)$.

\section{Copper}

A significant correlation between the copper concentration in the spleen and the age of bears $(\mathrm{r}=0.88, p<0.01)$ was estimated. Copper is an essential element that is a part of many enzymes. The highest concentrations were observed in the liver, followed by the kidney, spleen and muscle (diaphragm), respectively. Highly significant concentration differences were observed between the liver and spleen, spleen and kidney, liver and kidney, muscle (diaphragm) and liver $(p<0.001)$, and kidney and muscle (diaphragm) $(p<0.005)$. Copper concentration in the spleen was not significantly different from the muscle (diaphragm) values.

The copper content in the kidney and muscle (diaphragm) was identical with the values published by Žilinčar et al. (1992). The concentration in the liver was significantly higher $(p<0.01)$ compared to Žilinčar et al. (1992) but identical with values reported by Medvedev (1999).

It is alarming that cadmium and lead concentrations determined in the kidney and liver of examined bears are still too high, mercury levels have even increased compared to values determined between 1988 and 1990. Relatively high concentrations of toxic elements were found also in tissues of foxes, boar (Piskorová et al. 2003) and deer (Gašparik et al. 2004). However, these levels are lower than those observed in bears and are in accordance with the assumption that the heavy metal load of omnivores is higher than that of ruminants living in the same area (Chudík and Maňkovská 1987). Although emissions of toxic elements have been decreasing since 1990 (Keegan et al. 2006), they are more acid and the mean soil acidification ( $\mathrm{Schw}$ artz et al. 1999) allows for easier infiltration of certain metals into the soil extract and thus into plants. Thus metals become a part of the food chain of bears and other animals. This is also supported by recent reports on high heavy metal concentrations in mushrooms growing in the Spiš area, Slovakia (Zimmermannová 
et al. 2001). Indeed, an increasing synanthropy of the western Carpathians bears can affect the heavy metal content in their tissues (Langgemacht et al. 1995).

\section{Těžké kovy ve tkáních medvěda hnědého z Karpat}

Cílem předkládané práce bylo zhodnotit zatížení medvěda hnědého (Ursus arctos) ze západních Karpat těžkými kovy. V letech 2002-2004 bylo vyšetřeno 15 medvědů na obsah kadmia, olova, rtuti a mědi a byla vyhodnocena distribuce kovů do svaloviny (bránice), sleziny, jater a ledvin. Nejvyšší koncentrace kadmia, olova a rtuti byly v ledvinách $\left(17,4 \pm 5,2 \mathrm{mg} \cdot \mathrm{kg}^{-1}, 1,16 \pm 0,39 \mathrm{mg} \cdot \mathrm{kg}^{-1}, 0,39 \pm 0,25 \mathrm{mg} \cdot \mathrm{kg}^{-1}\right)$, nejnižší ve svalovině $\left(0,017 \pm 0,009 \mathrm{mg} \cdot \mathrm{kg}^{-1}, 0,299 \pm 0,308 \mathrm{mg} \cdot \mathrm{kg}^{-1}, 0,013 \pm 0,011 \mathrm{mg} \cdot \mathrm{kg}^{-1}\right)$. Druhé nejvyšší koncentrace kadmia, olova a rtuti byly nalezeny játrech $\left(0,83 \pm 0,24 \mathrm{mg} \cdot \mathrm{kg}^{-1}, 0,99 \pm 0,61\right.$ $\left.\mathrm{mg} \cdot \mathrm{kg}^{-1}, 0,11 \pm 0,05 \mathrm{mg} \cdot \mathrm{kg}^{-1}\right)$. Distribuce mědi do tkání medvěda byla $\mathrm{v}$ sestupném pořadí koncentrace: játra $\left(23,9 \pm 6,7 \mathrm{mg} \cdot \mathrm{kg}^{-1}\right)>$ ledviny $\left(9,0 \pm 3,3 \mathrm{mg} \cdot \mathrm{kg}^{-1}\right)>$ svalovina $\left(1,9 \pm 1,6 \mathrm{mg} \cdot \mathrm{kg}^{-1}\right)>$ slezina $\left(1,0 \pm 0,2 \mathrm{mg} \cdot \mathrm{kg}^{-1}\right)$. Ve srovnání se zjištěnými koncentracemi těžkých kovů ve tkáních medvědů z období 1988-1990 byly koncentrace kadmia ve svalovině a játrech významně nižší $(p<0,01)$, u rtuti došlo naopak ke statisticky významnému zvýšení u jater $(p<0,05)$, ledvin a svaloviny $(p<0,01)$. U olova a mědi nedošlo k podstatným změnám v koncentracích ve tkáních.

\section{Acknowledgements}

This research was supported by the Ministry of Education, Youth and Sports Physical Training of the Czech Republic, Project MSM No 6215712402.

\section{References}

BEIGLBOCK C, STEINECK T, TATARUCH F, RUF T 2002: Environmental cadmium induces histopathological changes in kidneys of roe deer. Environ Toxicol Chem 21: 1811-1816

BRAUNE B, MUIR D, DEMARCH B, GAMBERG M, POOLE K, CURRIE RET AL 1999: Spatial and temporal trends of contaminants in Canadian Arctic freshwater and terrestrial ecosystems: A review. Sci Total Environ 230: $145-207$

CHUDÍK I, MAŇKOVSKÁ B 1989: Industrial Air Pollution and theWildlife. Lesnictví 35: 65-76

DIETZ R, RIGET F, BORN EW 2000: Geographical differences of zinc, cadmium, mercury and selenium in polar bears (Ursus maritimus) from Greenland. Sci Total Environ 245: 25-47

GAŠPARIK J, MASSANYI P, SLAMEČKA J, FABIŠ M, JURČIK R 2004: Concentration of selected metals in liver, kidney, and muscle of the red deer (Cervus elaphus) J Environ Sci Heal A 39: 2105-2111

GNAMUS A, HORVAT M, STEGNAR P 1995: The mercury content among deer and of browsed foliage as a means of ascertaining environmental-pollution of the mining regions Idrija - a case- study from Slovenia. Z Jagdwiss 41: 198-208

GNAMUS A, BYRNE AR, HORVAT M 2000: Mercury in the soil- plant-deer-predator food chain of a temperate forest in Slovenia. Environ Sci Technol 34: 3337-3345

GUFLER H, TATARUCH F, ONDERKA K 1997: Investigation of the lead, cadmium, and mercury contents in the organs and muscles of roe deer and chamois in southern Tyrol. Z Jagdwiss 43: 240- 250

HELL P, PLAVÝ R, SLAMEČKA J, GAŠPARIK J 2005: Losses of mammals (Mammalia) and birds (Aves) on roads in the Slovak part of the Danube Basin. Eur J Wildlife Res 51: 35-40

HOEKSTRA PF, BRAUNE BM, ELKIN B, ARMSTRONG FAJ, MUIR DCG 2003: Concentrations of selected essential and non-essential elements in arctic fox (Alopex lagopus) and wolverines (Gulo gulo) from the Canadian Arctic. Sci Total Environ 309: 81-92

KOMARNICKI GJK 2005: Lead and cadmium in indoor air and the urban environment. Environ Pollut 136: 47-61

KOTTFEROVÁ J, KORÉNEKOVÁ B 2000: Game as an indicator of environmental pollution by cadmium and lead. J Trace Microprobe T 18: 571-575

KEEGAN TJ, FARAGO ME, THORNTON I, BING HONG, COLVILE RN, PESCH B, JAKUBIS P, NIEUWENHUIJSEN M.J 2006: Dispersion of As and selected heavy metals around a coal-burning power station in central Slovakia. Sci Total Environ 358: 61-71

KRAMÁROVÁ M, MASSANYI P, SLAMEČKA J, TATARUCH F, JANČOVÁ A, GAŠPARIK J, FABIŠ M, KOVÁČIK J, TOMAN R, GALOVÁ J, JURČIK R 2005: Distribution of cadmium and lead in liver and kidney, of some wild animals in Slovakia. J Environ Sci Heal A 40: 593-600

LANGGEMACHT T, DEUTRICH V, METZ R 1995: Investigation of heavy-metal concentrations in game animals in areas treated with human sewage. Tierarztl Umschau 50: 480-488 
MACDONALD RW, BARRIE LA, BIDLEMAN TF, DIAMOND ML, GREGOR DJ, SEMKIN RG, STRACHAN WMJ, LI YF, WANIA F, ALAEE M, ALEXEEVA LB, BACKUS SM, BAILEY R, BEWERS JM, GOBEIL C, HALSALL CJ, HARNER T, HOFF JT, JANTUNEN LMM, LOCKHART WL, MACKAY D, MUIR DCG, PUDYKIEWICZ J, REIMER KJ, SMITH JN, STERN GA, SCHROEDER WH, WAGEMANN R,YUNKER MB 2000: Contaminants in the Canadian Arctic: 5 years of progress in understanding sources, occurrence and pathways. Sci Total Environ 254: 93-234

MACDONALD RW, HARNER T, FYFE J 2005: Recent climate change in the Arctic and its impact on contaminant pathways and interpretation of temporal trend data. Sci Total Environ 342: 5-86

MASSANYI P, TRANDZIK J, STRAPÁK P, KOVÁČIK J, SIMO K, LUKÁŠ N, TOMAN R 2000a: Contamination of bovine insemination doses with cadmium, copper, lead and zinc and its relation to semen activity. J Environ Sci Heal A 35: 1637- 1644

MASSANYI P, UHRIN V, SIROTKIN AV, PAKSY K, FORGÁCS ZS, TOMAN R, KOVÁC̆IK J, 2000b: Effects of cadmium on ultrastructure and steroidogenesis in cultured porcine ovarian granulosa cells. Acta Vet Brno 69: 101-106

MASSANYI P, UHRIN V, TOMAN R, PIVKO J, LUKÁŠ N, FORGÁCS ZS, SOMOSY Z, FABIŠ M, DANKO J 2005: Ultrastructural Changes of Ovaries in Rabbits Following Cadmium Administration. Acta Vet Brno 74: 29-35

MEDVEDEV N 1999: Levels of heavy metals in Karelian wildlife. Environ Monit Assess 56: 177-193

MIADOKOVÁ E, VLČKOVÁ V, JENDRASSÁKOVÁ N, VLČEK D, SUCHÁ V 2000: Mutagenic and comutagenic effects of acid-mine water containing heavy metals. J Trace Microprobe T 18: 201-207

MUIR D, BRAUNE B, DEMARCH B, NORSTROM R, WAGEMANN R, LOCKHART L, HARGRAVE B, BRIGHT D, ADDISON R, PAYNE J, REIMER K 1999: Spatial and temporal trends and effects of contaminants in the Canadian Arctic marine ecosystem: A review. Sci Total Environ 230: 83-144

NRIAGU JO 1988: A silent epidemic of environmental metal poisoning. Environ Pollut 50: 139-161

NRIAGU JO 1991: Human influence on the global cycling of trace metals. In: FARMER JG (Ed.) Heavy metals in the environment 1. Edinburgh.

NRIAGU JO, PACYNA JM 1988: Quantitative assessment of worldwide contamination of air, water and soils with trace metals. Nature 333:134-139

PISKOROVÁ K, VASILKOVÁ Z, KRUPICER I 2003: Heavy metal residues in tissues of wild boar (Sus scrofa) and red fox (Vulpes vulpes) in the Central Zemplin region of the Slovak Republic. Czech J Anim Sci 48: 134-138

SCHWARTZ A, WILCKE W, STYK J, ZECH W 1999: Heavy metal release from soils in batch pH (stat) experiments. Soil Sci Soc Amer J 63: 290-296

TATARUCH F, ONDERSCHEK K 1981: Belastung freilebender tiere in Österreich mit Umweltschadstoffen. Z Jagdwiss 27:153-160

WILCKE W, MOSBACH J, KOBZA J, ZECH W 1998: Distribution of Al and heavy metals in bulk soil and aggregates at three sites contaminated by the emissions of a central Slovak Al smelter. Water Air Soil Poll 106: 389-402

WILCKE W, GUSCHKER C, KOBZA J, ZECH W 1999: Heavy metal concentrations, partitioning, and storage in Slovak forest and arable soils along a deposition gradient. J Plant Nutr Soil Sc 162: 223-229

WOSHNER VM, O'HARA TM, BRATTON GR, SUYDAM RS, BEASLEY VR 2001a: Concentrations and interactions of selected essential and non-essential elements in bowhead and beluga whales of arctic Alaska. J Wildlife Dis 37: 693-710

WOSHNER VM, O'HARA TM, BRATTON GR, BREASLEY VR 2001b: Concentrations and interactions of selected essential and non-essential elements in ringed seals and polar bears of arctic Alaska. J Wildlife Dis 37 : 711-721

YAAQUB RR, DAVIES TD, JICKELLS TD, MILLER JM, 1991: Trace elements in daily collected aerosols at a site in south-eastern England. Atmos Environ 25: 985-996.

ZIMMERMANNOVÁ K, SVOBODA L, KALAČ P 2001: Mercury, cadmium, lead and copper contents in fruiting bodies of selected edible mushrooms in contaminated Middle Spis region, Slovakia. Ecologia-Bratislava 20: 440-446

ŽILINČAR J, ZVADA P, KUBIN D, HELL P 1992: The presence of heavy-metals in brown bears in the West Carpathian mountains. Z Jagdwiss 38: 235-243 